Summer 1994

\title{
Murder, Capital Punishment, and Deterrence: A Review of the Evidence and an Examination of Police Killings.
}

\author{
William C. Bailey \\ Cleveland State University, w.bailey@csuohio.edu \\ Ruth Peterson \\ The Ohio State University, peterson.5@sociology.osu.edu
}

Follow this and additional works at: https://engagedscholarship.csuohio.edu/clsoc_crim_facpub

Part of the Criminology Commons, and the Law Enforcement and Corrections Commons

How does access to this work benefit you? Let us know!

\section{Original Citation}

Bailey, W. C., \& Peterson, R. D. (1994). Murder, capital punishment, and deterrence: A review of the evidence and an examination of police killings. Journal Of Social Issues, 50(2), 53-74.

\section{Repository Citation}

Bailey, William C. and Peterson, Ruth, "Murder, Capital Punishment, and Deterrence: A Review of the Evidence and an Examination of Police Killings." (1994). Sociology \& Criminology Faculty Publications. 33.

https://engagedscholarship.csuohio.edu/clsoc_crim_facpub/33

This Article is brought to you for free and open access by the Sociology \& Criminology Department at EngagedScholarship@CSU. It has been accepted for inclusion in Sociology \& Criminology Faculty Publications by an authorized administrator of EngagedScholarship@CSU. For more information, please contact library.es@csuohio.edu. 


\title{
Murder, Capital Punishment, and Deterrence: A Review of the Evidence and an Examination of Police Killings
}

\author{
William C. Bailey
}

Cleveland State University

Ruth D. Peterson

Ohio State University

This paper reviews and assesses the empirical literature on murder, capital punishment, and deterrence. There is a large body of evidence regarding these issues, with studies yielding a rather consistent pattern of nondeterrence. However, most investigations are limited because they rely upon the general homicide rate as the criterion variable, although both legally and theoretically, different types of murder may be differentially subject to deterrence. As an example of how deterrence investigations may benefit from examining different types of homicide, we conduct a monthly time-series analysis of the possible deterrent effect of the provision for capital punishment, levels of execution, and the amount and type of television news coverage executions receive on overall and different types of police killings for 1976-1989. The analysis reveals no evidence that police are afforded an added measure of protection against death by capital punishment.

Academics and others have long debated whether capital punishment is effective in deterring murder. In this analysis we (1) assess the state of knowledge regarding murder, capital punishment and deterrence; (2) explicate the need to consider different types of homicide in examining the deterrence question; and (3) examine the possible deterrent effect of capital punishment on lethal assaults against police.

Correspondence regarding this article should be addressed to William C. Bailey, Graduate College, Cleveland State University, Cleveland, $\mathrm{OH} 44115$. 


\section{Deterrence Theory and Capital Punishment}

Deterrence theory rests upon the premise that individuals weigh the costs and rewards associated with alternative actions, and choose behaviors that yield the greatest gain at the least cost. Thus, crime occurs when illegal actions are perceived either as more profitable (rewarding) or less costly (painful) than conventional alternatives. In this context, the purpose of criminal sanctions is to prevent crime. Crime prevention is achieved through providing a system of sanctions that (1) convinces would-be criminals that crime does not pay (general deterrence) and (2) prevents recidivism by teaching a direct lesson to those who were not deterred (special deterrence). To achieve maximum deterrence, sanctions must be severe enough to outweigh the benefits derived from crime, administered with certainty, administered promptly, and made known to would-be offenders. However, the hypothesized negative effects of these dimensions of punishment on crime are contingent rather than additive. For example, regardless of their degree of severity, sanctions cannot deter if their level of certainty is zero or near zero.

Deterrence theorists view murder as rational behavior, and assume that in calculating the gains and losses from killing, potential offenders are aware of the death penalty and regard it as a more severe sanction than imprisonment. Because the threat of one's own death presumably outweighs the rewards gained from killing another, murder is discouraged. In addition, some noted proponents contend that capital punishment provides an important educative function in society by validating the sanctity of human life (Berns, 1979; van den Haag, 1975; van den Haag \& Conrad, 1983).

Despite this logic, some challenge the applicability of deterrence to murder. Rather than being a product of deliberation and calculation, it is contended that most murders are emotionally charged and spontaneous events; they are "acts of passion" or result from a situated transaction rather than from deliberation (Bowers \& Pierce, 1980; Chambliss, 1967; Luckenbill, 1977). Indeed, a significant proportion of homicides may not be intended. The situation simply gets out of hand, or due to some extraneous factor, the assault victim dies. Under such conditions, it is unlikely that offenders ("killers") give serious thought to whether they reside in a death penalty jurisdiction, or the possibility of execution.

Some critics also question whether the message conveyed by executions underscores the sanctity of life. Proponents of what has become known as the brutalization thesis contend that the message communicated by executions is lethal vengeance and a disrespect for human life.

Executions demonstrate that it is correct and appropriate to kill those who have gravely offended us. The fact that such killings are to be performed only by duly appointed officials on duly convicted offenders is a detail that may get obscured by the message that such offenders deserve to die. (Bowers \& Pierce, 1980, p. 456) 
Indeed, some of the most important founders of the general deterrence doctrine were opposed to the death penalty because they were convinced that capital punishment (unlike other types of sanctions) communicates that it is proper to kill those who have wronged us, and in so doing, puts the lives of citizens at greater risk (Beccaria, 1764/1963; Bentham, 1843/1962).

\section{The Empirical Research}

Despite considerable research, the deterrence/brutalization issue has not been resolved. Studies can be divided into three general categories based upon chronology, methodology, and substantive concerns.

\section{Early Comparative Studies}

Early observers drew nondeterrence conclusions about capital punishment based upon rather casual comparisons of the frequency (not rates) of homicides before and after executions, and for death penalty and abolitionist jurisdictions. These "studies" were simply too crude to yield meaningful results. This realization prompted a series of investigations in the U.S. spanning the early 1900s through the mid-1960s that compared (1) homicide rates for contiguous or otherwise matched death penalty and nondeath penalty states (Savitz, 1958; Schuessler, 1952; Sellin, 1967; Sutherland, 1925), and (2) homicide rates for states before and after the abolition and/or reinstatement of the death penalty (Bedau, 1967; Schuessler, 1952; Sellin, 1955, 1959, 1967). Contiguous state and before/after analyses provided the advantage of controlling for important nonpunishment factors that influence homicide rates.

These analyses did not provide support for the deterrence argument. Rather, murder rates were often found to be higher in death penalty jurisdictions, and abolition and/or reintroduction of capital punishment was sometimes followed by an increase in murders and sometimes not. Based on this evidence, most criminologists came to agree with Sellin's $(1967$, p. 138) conclusion that "the presence of the death penalty in law and practice has no discernible effect as a deterrent to murder."

\section{Ehrlich's Work and Econometric Modeling}

This conclusion was challenged in the mid-1970s by Isaac Ehrlich (1975). He dismissed previous death penalty studies as inadequate due to their failure (1) to treat the certainty of capital punishment as an important deterrence variable, and (2) to consider as formal control variables other factors that influence homicides. To address these problems, Ehrlich examined annual execution and homicide data for 1933-1969 while statistically controlling for the influence of vari- 
ous sociodemographic and law enforcement variables. He found a significant inverse relationship between execution and homicide rates. This led him to conclude that the death penalty has a substantial deterrent effect. Indeed, Ehrlich reported that on average during the period each execution was associated with seven to eight fewer murders.

The immediate response to Ehrlich's study was a series of replications of his national time-series analysis (Bowers \& Pierce, 1975; Passell \& Taylor, 1975; Yunker, 1976). These efforts did not substantiate his findings. Rather, they pointed to a number of theoretical and methodological concerns about Ehrlich's analysis. For example, when the last few years of the 1933-1969 time series were removed from the analysis, evidence of possible deterrence disappeared.

Others applied Ehrlich-type models in time-series investigations (Bailey 1978, 1979a, 1979b, 1979c, 1979d, 1979-80; Decker \& Kohfeld, 1990) or cross-sectional analyses of state execution and murder rates (Bailey, 1974, 1975, 1977, 1980a, 1980b, 1983, 1984a, 1984b; Black \& Orsagh, 1978; Ehrlich, 1977; Forst, 1977; Passell, 1975; Peterson \& Bailey, 1988). With few exceptions (Ehrlich, 1977; Layson, 1985), these efforts also failed to substantiate Ehrlich's findings. Moreover, some studies indicated that the death penalty actually may contribute to homicides (Bowers, 1984, 1988; Bowers \& Pierce, 1980).

\section{Studies of Execution Publicity}

The above noted analyses were impressive, but they ignored the possible deterrent effect of the publicity surrounding executions. As Gibbs (1975) notes, deterrence is a communication theory. Regardless of their severity and certainty, criminal sanctions can influence perceptions, and accordingly the behavior of potential offenders, only if they are made public. Prior to 1978, this issue had been addressed in just two investigations. Dann (1935) examined the number of possible capital homicides (killings that appeared to involve premeditation, and those involving the commission of another crime) for the 60-day period before and after five highly publicized executions in Philadelphia in 1927, 1929, 1930, 1931, and 1932. He found an increase, not a decline, in killings following each execution. A follow-up analysis by Savitz (1958) of definite and possible capital homicides in Philadelphia before and after four highly publicized death sentences (not executions) in 1944, 1946 (two), and 1947 also produced no evidence of deterrence. Although informative, these studies were very limited because they considered only a single jurisdiction and examined a very small number of executions.

In a more systematic publicity analysis, King (1978) examined the impact of newspaper coverage of executions on monthly homicides in South Carolina for the period 1951-1962. He found that "there were almost as many [execution] story months accompanied by fewer homicides than expected ( 8 months) as there were story months accompanied by more homicides than expected (11 months)" 
(1978, p. 685). Also, Phillips (1980) examined weekly homicide counts in London, England, before and after 22 highly publicized executions between 1858 and 1921 . He found that the number of homicides declined by approximately 35\% during the two weeks following the executions. However, Phillips also observed a significant "rebound" effect. Killings returned to their baseline levels during the third through the fifth weeks after executions. Bowers' (1988) analysis confirmed that, at best, publicized executions had the effect of postponing not deterring homicides. Indeed, correcting for an important coding error in Phillips' analysis, Bowers found a significant net increase in homicides during the six to ten weeks following executions.

Considering possible deterrent and rebound effects, McFarland (1983) examined national and regional homicide counts for weekly periods leading up to and succeeding four highly publicized executions that followed a 10-year moratorium (1967-1976) on capital punishment in the U.S.: Gary Gilmore (January 1977), John Spinkellink (May 1979), Jesse Bishop (October 1979), and Steven Judy (March 1981). An interrupted time-series analysis showed that none of the executions was followed by a significant decline in killings that could be attributed to deterrence.

The King (1978), Phillips (1980), and McFarland (1983) studies are improvements over the earlier analyses by Dann (1935) and Savitz (1958), but they too suffer from important limitations. Of note: (1) they do not measure the actual amount and type of media attention devoted to executions, and (2) they fail to consider systematically alternative (history) factors that might have influenced homicides during the pre- and postperiods examined. More recent studies have addressed these concerns (Bailey, 1990; Bailey \& Peterson, 1987; Stack, 1987, 1990).

Stack (1987) examined the correspondence between U.S. monthly homicide rates and levels of print media attention devoted to executions for the 1950-1980 period. He reported a significant decline in homicide rates for months with highly publicized executions. Stack estimates that "16 [highly] publicized executions may have saved as many as 480 lives" $(1987$, p. 538). Stack (1990) also reports evidence of deterrence in a reanalysis of the King (1978) data for South Carolina.

A replication and extension of the first Stack (1987) analysis by Bailey and Peterson (1989) showed that Stack's findings were a result of various shortcomings of his analysis, including (1) the use of a highly unorthodox measure of the homicide rate (the number of homicide victims of all ages per 100,000 population of persons 16 years of age and older); (2) ignoring changes over the period in the volume of monthly executions, the arrest clearance rate for homicides, and a variety of sociodemographic factors associated with murder rates; and (3) coding errors for the execution publicity variables. Merely correcting the coding errors resulted in a chance association between the execution publicity and homicide rates for the 1950-1980 period. This null pattern remained when the other limitations were addressed, and when the time series was extended from 1940 to 1986. 
Bailey (1990) conducted a monthly analysis of the impact of television news coverage of executions during the 1976-1987 period. He found only a chance association between homicide rates and the amount of television news coverage devoted to executions. He also observed no consistent evidence of deterrence when different types of news coverage were aired, e.g., very graphic vs. matterof-fact presentations of persons being put to death.

\section{An Assessment of the Empirical Evidence}

Deterrence and capital punishment studies have yielded a fairly consistent pattern of nondeterrence. Thus, some would conclude that the capital punishment and deterrence question has been resolved. However, in our view, the body of research indicates only that the overall (general) homicide rate is not responsive to capital punishment. It is still possible that some forms of killing may be deterred by capital punishment, while other types of murder may be encouraged (brutalization) by the death penalty.

To address this issue, future researchers should consider different dependent variables. First, it is important to consider types of homicide that are eligible for the death penalty. The deterrence perspective assumes that citizens' perceptions of costs and rewards are a consequence of the objective gains and losses associated with a given action. Thus, one might expect capital punishment to have a significant deterrent effect only for death-eligible killings. In the U.S., these mainly include first-degree murder (intentional killings) and murders that result from the commission of certain other felonies (e.g., rape, robbery, arson). It is estimated that intentional killings constitute about $5 \%-10 \%$ of criminal homicides, and felony murders account for $20 \%-25 \%$ of all homicides (Peterson \& Bailey, 1991). Unfortunately, death penalty investigations have relied upon published figures that do not distinguish capital from noncapital homicides. The exceptions are the limited execution publicity studies (Dann, 1935; Savitz, 1958), which do not provide an adequate basis for drawing firm conclusions.

In addition to examining capital homicides, it is important to investigate how various homicide characteristics and circumstances may condition the possible effect of capital punishment. For example, the literature suggests that racial and ethnic minorities are disproportionately subject to capital punishment. This raises the question of whether African Americans, Hispanics, and other minorities may be more responsive than whites to the death penalty. Also, some populations (based on gender, race, ethnicity, income, occupation, and the like) may be afforded more or less protection by capital punishment. For example, are those in criminal justice occupations afforded an added measure of protection against death compared to others? These types of questions have seldom been examined.

Along different lines, it has been suggested that criminal sanctions are more effective as deterrents for instrumental than expressive crimes (Chambliss, 1967; 
Gibbs, 1975; Zimring \& Hawkins, 1986). As described by Chambliss (1967), expressive crimes are shrouded with emotional involvement and are committed because the acts themselves are gratifying; instrumental crimes are dictated more by rational considerations and are committed to attain some other goal. Above we noted that many homicides are expressive (i.e., acts of passion) but some are instrumental (e.g., murder for hire). Researchers have not yet examined whether homicides that fall into these two categories are more or less subject to deterrence.

More generally, research is needed to determine whether killings involving various victim-offender relationships and circumstances (e.g., husbands killing wives, parents killing children, killings resulting from arguments among friends) are more or less responsive to capital punishment. Some of these types of murder may not be capital homicides. Still, they may be discouraged or encouraged by capital punishment due to characteristics of the parties and circumstances involved.

Until recently, researchers did not have access to homicide data that were refined enough to determine the capital and noncapital nature of killings, or the extent to which deterrence depends upon other offense and victim-offender characteristics. Currently, detailed U.S. homicide data are available from the Federal Bureau of Investigation (FBI) that can be used to form offending and victimization rates for a wide variety of types of murder. Thus, it is now possible to begin to address some of the unresolved issues regarding deterrence and capital punishment. The analysis to follow is a step in this direction. We examine the impact of capital punishment on police killings which are death-eligible homicides in all U.S. retentionist jurisdictions. It has been proposed that police gain an added measure of protection against murder because the death penalty deters persons from carrying lethal weapons and using them against the police when they are in danger of arrest (van den Haag \& Conrad, 1983). Further, some insist that the death penalty is the only sanction that can restrain suspects in danger of being arrested for a crime that could lead to life imprisonment. For example, van den Haag (van den Haag \& Conrad, 1983, p. 234) notes,

Without the death penalty an offender having committed a crime that leads to imprisonment for life has nothing to lose if he murders the arresting officer. By murdering the officer . . . such criminals increase their chances of escape, without increasing the severity of the punishment they will suffer if caught.

\section{Capital Punishment and Police Killings}

\section{Previous Research}

Several investigations have considered whether capital punishment affords police an added measure of protection (Bailey, 1982; Bailey \& Peterson, 1987; Sellin, 1955). Sellin (1955) reasoned that if the death penalty deters lethal assaults against officers, then police killings should be lower in retentionist juris- 
dictions. Based on a survey of police departments in U.S. cities with a population of at least 10,000 (in 1950) in 17 death penalty and six abolitionist jurisdictions, he examined annual police killing rates per 100,000 population for the period 1919-1954. Sellin found that the average police homicide rate for cities in death penalty (1.3) and abolitionist (1.2) states was virtually identical.

Although the length of the time period (1919-1954) and the number of jurisdictions (265) examined are impressive, Sellin used a very unorthodox measure of the rate of police killings: the total number of police homicides per 10,000 general, not police, population. Correcting for this problem, Bailey (1982) examined annual police homicide rates for abolitionist and death penalty states (1961-1971) computed on the basis of the number of police killings per 1000 police officers. He found that average rates were not significantly different for the two types of jurisdictions for any year.

Bailey (1982) also examined the relationship between the certainty of execution for murder and police killings. For each year (1961-1967), police homicide rates were regressed against the ratio of total executions to total criminal homicides, a dummy variable differentiating death penalty from abolitionist states, and four control variables - the percents urban, black population, and poverty, and the unemployment rate. Bailey did not find that policing is less hazardous in death penalty states, or that the level of execution is associated with police killings. An extension of this analysis for the 1973-1984 period also produced chance-only associations between state-level police killing rates and the provision for and certainty of capital punishment (Bailey \& Peterson, 1987).

In sum, several investigations have examined the deterrence argument for police killings, but none has found that rates are associated with capital punishment. However, the studies have not provided a proper test of the certainty argument. This issue was not considered by Sellin (1955). And in Bailey (1982) and Bailey and Peterson (1987) the certainty of capital punishment was measured as the ratio of total executions (or death sentences) to the total number of homicides, rather than the ratio of the number of executions for police killings to the number of police homicides. Also, none of the police killings studies has considered the publicity hypothesis. This is an important omission since deterrence theory rests on the assumption that to discourage crime, sanctions must be communicated.

The dependent variables considered in the above analyses are also problematic. First, Sellin used the size of the general rather than the police population as the denominator in computing police killing rates. Second, the investigations use the total number of police killings as a numerator in constructing rates. However, all types of police killings may not be equally subject to deterrence. For example, it is possible that on-duty police but not off-duty police are afforded an added measure of protection by capital punishment. Off-duty police killings often take place in situations where an apparent civilian is being robbed or a home is being 
burglarized. Similarly, it is possible that general jurisdiction officers (e.g., city police, county sheriffs, and state patrol) gain a measure of protection from capital punishment, but specialized officers (e.g., fish and game protectors, customs agents, immigration and naturalization authorities, public housing and transit security) do not. Finally, previous analyses have relied upon annual data to construct execution, police killing, and control variables. However, if the deterrent effect of capital punishment is short-lived or very slight, this effect may not be evident when the data are aggregated on an annual basis.

\section{The Present Investigation}

In this investigation we address each of these limitations. Considering the 1976-1989 period, we conduct a national monthly time-series analysis of the relationship between rates of overall and different types of police killing, and (1) the levels of execution for all murder, as well as executions for police killings, and (2) the amount and type of media attention devoted to executions.

The time period. The analysis spans the 168 -month period from January 1976 through December 1989. Required television execution publicity data are available from the Vanderbilt Television News Archives from 1968 through the early months of 1993. (There were no executions in the U.S. from 1968 through 1976.) However, at the time of this analysis, appropriate police homicide figures were available only through 1989.

Police killings: The dependent variable. During the 1976-1989 period, 1204 law enforcement officers were killed feloniously. Based on these data, we employ five measures of the rate of police killings. Our most general measure is the monthly rate of police homicides per 100,000 law enforcement personnel. To examine whether various types of police homicide are differentially subject to deterrence, we also compute monthly rates for killings of (1) on-duty and (2) offduty police, and killings of (3) general jurisdiction police vs. (4) special police.

Required police homicide data are drawn from the annual FBI publication, Police Officers Killed and Assaulted for the 1987-1989 period. Police employee data are taken from annual Bureau of Census publications. Linear interpolation is used to estimate monthly police employee figures. In calculating rates of police killing, we use as a denominator the total number of U.S. federal, state, and local law enforcement employees, rather than the number of sworn law enforcement personnel. This is because figures on sworn police personnel are only available from the Bureau of the Census for 1987-1989. Using the more inclusive police employee data means that our rates understate the actual levels of police homicide because the number of sworn officers is smaller than the number of total police employees. 
This method of computing rates is justifiable if there was not a major shift over the 1976-1989 period in the ratio of total to sworn police personnel. Unfortunately, data on the number of sworn personnel are not available to test this question at the national level for 1976-1986. However, at the state and local levels, data for the total number of police employees and the number of sworn personnel are available, and the national counts of the two are correlated almost perfectly $(r=.985$ to .995$)$. Since most police employment (total and sworn) is at the state or local level (for 1989: total $=90.2 \%$, sworn $=87.2 \%$ ), the total number of police employees likely provides a good proxy for sworn personnel.

Nonetheless, we employ an additional strategy that controls for changes in the number of police available to be killed over the period. Specifically, we conduct a first-difference analysis where the variables of interest are operationalized in terms of difference scores that are derived by subtracting the values of the variables for the current month (month $t$ ) from the values of the variables for the previous month (month $t-1$ ). Thus, the first-difference analysis examines the correspondence between month-to-month changes in police killings and in the death penalty variables while holding constant month-to-month changes in the control variables.

Status of the death penalty. Over the 1976-1989 period there was considerable variation in the proportion of the U.S. population subject to capital punishment due to legislative and judicial action. To control for the portion of the country not subject to capital punishment, we have computed a percent abolition population variable based upon the ratio of (1) the size of the population residing in abolitionist jurisdictions to (2) the total U.S. residential population. This variable acts as a proxy for the percent of police officers working in jurisdictions without capital punishment.

Certainty of execution. Two measures of the certainty of execution are used: (1) the total number of monthly executions for murder $(n=120)$ during the 168month period, and (2) the number of executions associated with police killings $(n$ $=12$ ). Of note, a slightly higher proportion of executions resulted from police homicides $(12 / 1204=.0099)$ than from civilian killings $(120 / 285,360=.0004)$ during the 1976-1989 period.

Execution publicity. We consider television news in examining the effect of execution publicity on police killings. In recent decades Americans have come to rely upon television more than all other media sources combined for their daily news. Television is seen as providing the most "complete," "intelligent," and "unbiased" source of news (Bower, 1985; The Roper Organization, 1983). The Vanderbilt Television News Archive provides the source of the publicity data. 
Drawing upon Bailey (1990), we alternately consider three measures of the amount of television execution publicity in our models of police killings. We (1) differentiate between months $(0 / 1)$ where there was zero vs. some level of execution publicity, (2) sum the minutes per month of air time devoted to executions, and (3) add the number of days per month where there was execution publicity. Execution coverage occurring after the 23rd of the month is coded as taking place the following month (Bailey \& Peterson, 1989; Stack, 1987). For the period 1976-1989, there were 28 months with televised execution publicity.

Like Bailey (1990), we also consider different types of news coverage. We alternately examine as a series of dummy variables months where (1) artist's drawings were $(n=6)$, or were not, aired illustrating the condemned person's execution, (2) witness accounts were $(n=13)$, or were not, provided of the execution, and (3) the executed person's last words were $(n=10)$, or were not, presented. We also distinguish television coverage portraying offenders as "more" deserving of execution $(n=9)$. These include persons involved in multiple homicides, rape-murders, and the killing of children. Conversely, we differentiate coverage reflecting skepticism about certain executions $(n=9)$, including cases where (1) persons claimed their innocence to the end, (2) the executed individual was not the "trigger person," and the "real" killer received a lighter sentence, and (3) the youthful age or mental retardation of the offender prompted appeals for mercy from noted figures. Finally, we distinguish coverage that included antiexecution demonstrations $(n=11)$. In these cases, what might have been communicated is that capital punishment is not a legitimate sanction.

Our measures of television coverage pertain to all executions, and not just the execution of police killers. Twelve police killers were executed during the 1976-1989 period, but only three of the executions received television coverage. Three cases are not sufficient to examine the publicity hypothesis for police killings. One might also question whether there was a sufficient number of execution stories with more graphic and atypical content (e.g., artists drawings, $n=6$; eyewitness accounts, $n=13$ ) over the period to provide a reliable test of whether different types of media coverage are more or less effective in deterring police killings. Here, we can only speculate because there is no time period available where executions received more detailed and graphic television media coverage. National television news data regarding executions are not available from the Vanderbilt Television Archive or any other source before 1976, and since 1989 Archive records show that there has been no increase in the amount of time and detail given to executions in the evening news.

Control variables. Six control variables are considered in the analyses: percent metropolitan population, black population, persons in the crime prone years of 16-34, the divorce rate, the unemployment rate, and percent recipients 
of Aid for Families with Dependent Children (AFDC). These factors have been linked to homicide in previous research. Monthly AFDC figures were drawn from the Annual Statistical Supplement to the Social Security Bulletin. The Statistical Abstracts of the United States is the source for the remaining control variables.

Statistical analysis. The time-series analysis proceeds by first exploring the autoregressive process for each of the police killing measures. Using ordinary least squares (OLS) techniques, we regress each of the rate and first-difference police killing measures against the sanction and control variables. Possible significant autocorrelations were explored for periods ranging through $t-12$ months. Autocorrelation, also known as serial correlation, refers to the situation in a time-series analysis where errors associated with observations in a given time period carry over into a future time period. Generally, the presence of significant autocorrelation affects the efficiency of OLS parameter estimates. As Pindyck and Rubinfeld (1976, p. 107) note:

\footnotetext{
In the case of positive serial correlation, this loss of efficiency will be masked by the fact that the estimates of the standard errors obtained from the least-squares regression will be smaller than the true standard errors. [That is], the regression estimators will be . . . biased downward. This will lead to the [mistaken] conclusion that the parameter estimates are more precise than they actually are.
}

Where significant autocorrelations were found, they were fit using the SAS (Statistical Analysis System) Autoregression procedure. In these cases YuleWalker estimates are presented in the tables to follow. Where significant autocorrelations were not observed, OLS estimates are reported.

Multicollinearity is often a concern for this type of analysis. Multicollinearity refers to a situation where such strong interrelationships exist among predictor variables that it becomes difficult to disentangle their separate effects on the dependent variable. For example, when two or more predictor variables are correlated perfectly, or when one predictor is a perfect linear combination of two or more other predictors, it is impossible to derive reliable parameter estimates for the involved variables. In most multivariate situations, predictor variables are not totally independent, nor are they perfectly interrelated. Rather, collinearity is normally a matter of degree. To explore possible collinearity problems for the death penalty variables, the monthly execution and the execution publicity measures presented in Tables 1-4 were each regressed against the other right-hand variables in the analysis. These auxiliary regressions resulted in multiple $R^{2}$ values ranging from .022 to .221 for the rate models, and .015 to .183 for the first-difference models. These very low $R^{2}$ values indicate that the statistical estimates for the death penalty variables are not affected by collinearity problems. 


\section{Findings}

The findings are presented in several stages. We first report results for the analyses of rates of police killing when alternative measures of the amount of execution publicity are considered, and then when different types of publicity are examined. Next, we present the results of the first-difference analyses considering the amount and then types of news coverage given to executions.

\section{Results for the Rate Analyses}

Deterrence theory predicts a significant positive relationship between the proportion of the U.S. population residing in abolitionist jurisdictions and rates of police killing, and significant negative associations between rates and the levels of execution and execution publicity. Table 1 reports the analyses where monthly rates for all types of police killing are considered. All the models presented in the table include the control variables and the percent abolition factor. However, the various measures of execution certainty and execution publicity are considered in alternative models. Columns 2-4 present the analyses where the total number of executions is the certainty measure and the execution publicity measures are respectively a dummy variable distinguishing between months with and without execution publicity (column 2), the number of minutes of television coverage of executions (column 3), and the number of days of execution coverage (column 4). In columns 5-7 this analysis is repeated with the exception that the number of executions for police killing is the measure of certainty. The remaining tables (2-4) follow the same pattern of considering various combinations of execution and execution publicity variables.

The statistics in the tables are unstandardized partial regression coefficients (b) with their standard errors. The statistic $b$ provides a measure of the tradeoff between the dependent variable (police killings) and the predictor variable being examined. For example, in Table 1 , the $b$ value of -.088 for the execution publicity dummy variable (column 2) may be interpreted in the following manner. Holding constant the effects of the other predictor variables in the analysis for the 1976-1989 period, the police killing rate declined by an average of .088 persons during months where there was at least some television news coverage of executions. $R^{2}$ values are also reported in the tables. They indicate how well all of the predictor variables in combination account for variation in the dependent variable-monthly police killings. At the extremes, this "goodness-of-fit" measure can range from zero to one. In the present context, an $R^{2}$ value of zero would indicate that variation in the values of the predictor (and control variables) is totally unrelated to the level of police killings. Values of $R^{2}$ between zero and one indicate the degree of linear association between the predictor and homicide variables. 
Table 1. Monthly Autoregressive Analysis of Rates of Total Police Killings, Executions, and the Amount of Execution Publicity, 1976-1989

\begin{tabular}{|c|c|c|c|c|c|c|}
\hline Predictor Variables & $\begin{array}{c}2 \\
b \\
\text { (SE) }\end{array}$ & $\begin{array}{c}3 \\
b \\
\text { (SE) }\end{array}$ & $\begin{array}{c}4 \\
b \\
\text { (SE) }\end{array}$ & $\begin{array}{c}5 \\
b \\
(\mathrm{SE})\end{array}$ & $\begin{array}{c}6 \\
b \\
(\mathrm{SE})\end{array}$ & $\begin{array}{c}7 \\
b \\
(\mathrm{SE})\end{array}$ \\
\hline $\begin{array}{l}\% \text { Metropolitan pop- } \\
\text { ulation }\end{array}$ & $\begin{array}{l}.188 \\
(.189)\end{array}$ & $\begin{array}{l}.187 \\
(.185)\end{array}$ & $\begin{array}{l}.163 \\
(.190)\end{array}$ & $\begin{array}{l}.174 \\
(.185)\end{array}$ & $\begin{array}{l}.178 \\
(.185)\end{array}$ & $\begin{array}{l}.154 \\
(.188)\end{array}$ \\
\hline \% Black population & $\begin{array}{c}-.961^{*} \\
(.377)\end{array}$ & $\begin{array}{l}-.966^{*} \\
(.376)\end{array}$ & $\begin{array}{l}-.955^{*} \\
(.376)\end{array}$ & $\begin{array}{c}-.385 * * \\
(.374)\end{array}$ & $\begin{array}{l}-.998 * * \\
(.371)\end{array}$ & $\begin{array}{l}-.968 * * \\
(.372)\end{array}$ \\
\hline $\begin{array}{l}\% \text { 16-24 Years } \\
\text { of age }\end{array}$ & $\begin{array}{r}-.156 \\
(.121)\end{array}$ & $\begin{array}{l}-.156 \\
(.121)\end{array}$ & $\begin{array}{l}-.154 \\
(.121)\end{array}$ & $\begin{array}{r}-.163 \\
(.121)\end{array}$ & $\begin{array}{l}-.165 \\
(.121)\end{array}$ & $\begin{array}{l}-.159 \\
(.121)\end{array}$ \\
\hline Divorce rate & $\begin{array}{l}.847^{*} \\
(.419)\end{array}$ & $\begin{array}{l}.848 * * \\
(.417)\end{array}$ & $\begin{array}{l}.829 * \\
(.419)\end{array}$ & $\begin{array}{l}.868^{*} \\
(.418)\end{array}$ & $\begin{array}{l}.876 \\
(.415)\end{array}$ & $\begin{array}{l}.842 * \\
(.417)\end{array}$ \\
\hline Unemployment rate & $\begin{array}{c}.042 \\
(.042)\end{array}$ & $\begin{array}{c}.041 \\
(.043)\end{array}$ & $\begin{array}{c}.039 \\
(.043)\end{array}$ & $\begin{array}{c}.042 \\
(.043)\end{array}$ & $\begin{array}{l}.042 \\
(.043)\end{array}$ & $\begin{array}{c}.039 \\
(.043)\end{array}$ \\
\hline \% AFDC population & $\begin{array}{l}-.296 \\
(.352)\end{array}$ & $\begin{array}{l}-.297 \\
(.351)\end{array}$ & $\begin{array}{l}-.298 \\
(.351)\end{array}$ & $\begin{array}{r}-.310 \\
(.351)\end{array}$ & $\begin{array}{c}-.311 \\
(.350)\end{array}$ & $\begin{array}{l}-.306 \\
(.351)\end{array}$ \\
\hline $\begin{array}{l}\% \text { in Abolition juris- } \\
\text { dictions }\end{array}$ & $\begin{array}{l}.003 \\
(.012)\end{array}$ & $\begin{array}{l}.003 \\
(.013)\end{array}$ & $\begin{array}{l}.022 \\
(.013)\end{array}$ & $\begin{array}{l}.003 \\
(.012)\end{array}$ & $\begin{array}{l}.003 \\
(.013)\end{array}$ & $\begin{array}{c}.002 \\
(.013)\end{array}$ \\
\hline $\begin{array}{l}\text { No. of total execu- } \\
\text { tions }\end{array}$ & $\begin{array}{r}-.014 \\
(.033)\end{array}$ & $\begin{array}{r}-.002 \\
(.034)\end{array}$ & $\begin{array}{l}-.007 \\
(.033)\end{array}$ & - & - & - \\
\hline $\begin{array}{l}\text { No. of police-related } \\
\text { executions }\end{array}$ & - & - & - & $\begin{array}{l}.009 \\
(.103)\end{array}$ & $\begin{array}{l}.003 \\
(.100)\end{array}$ & $\begin{array}{l}.020 \\
(.103)\end{array}$ \\
\hline $\begin{array}{l}\text { TV publicity dummy } \\
(0 / 1)\end{array}$ & $\begin{array}{l}-.008 \\
(.094)\end{array}$ & - & - & $\begin{array}{r}-.027 \\
(.088)\end{array}$ & - & - \\
\hline $\begin{array}{l}\text { No. of minutes of } \\
\text { execution coverage }\end{array}$ & - & $\begin{array}{l}-.014 \\
(.031)\end{array}$ & - & - & $\begin{array}{l}-.003 \\
(.009)\end{array}$ & - \\
\hline $\begin{array}{l}\text { No. of days of exe- } \\
\text { cution coverage }\end{array}$ & - & - & $\begin{array}{l}-.027 \\
(.050)\end{array}$ & - & - & $\begin{array}{r}-.034 \\
(.046)\end{array}$ \\
\hline Intercept & .225 & .329 & 2.101 & $\begin{array}{r}1.743 \\
306\end{array}$ & $\begin{array}{r}1.592 \\
306\end{array}$ & 3.092 \\
\hline
\end{tabular}

Table 1 provides no indication of deterrence. For each model there is a very slight positive but nonsignificant association $(b=.002$ to .022$)$ between the percent of the U.S. population residing in abolitionist jurisdictions and police killing rates. There are also merely chance associations between rates and the total number of monthly executions $(b=-.002$ to -.014$)$ and the execution of police killers $(b=.003$ to .020$)$.

The pattern is similar for the execution publicity variables. Police killings are associated negatively with (1) the dummy variable that distinguishes between months with and without television coverage of executions $(b=-.008$ and $-.027)$, and (2) the number of minutes ( $b=-.014$ and -.003$)$, and (3) days $(b=-.027$ and -.034$)$ of execution coverage per month. In no case is the coefficient for a media variable significant.

Table 2 extends the rate analysis to explore whether different types of news coverage affect police killings. Rates of total police killing are regressed against the control, abolition population, number of total executions, and in turn, the six 
alternative media variables: news including artist's drawings of executions (column 2), witness accounts of executions (column 3), the executed person's last words (column 4), the execution of "deserving" persons (column 5), the execution of "nondeserving" persons (column 6), and anticapital punishment demonstrations (column 7).

Again there is no indication of deterrence. The police homicide rate is associated negatively with the number of monthly executions $(b=-.003$ to -.018 ), but the coefficients are slight and nonsignificant. Also, execution stories involving witness accounts, the presentation of the condemned person's last words, and the execution of "deserving" persons are associated with slightly lower rates of police killing, but not significantly so. Conversely, artist drawings,

Table 2. Monthly Autoregressive Analysis of Rates of Total Police Killings, Executions, and Type of Execution Publicity, 1976-1989

\begin{tabular}{|c|c|c|c|c|c|c|}
\hline Predictor Variables & $\begin{array}{c}2 \\
b \\
\text { (SE) }\end{array}$ & $\begin{array}{c}3 \\
b \\
\text { (SE) }\end{array}$ & $\begin{array}{c}4 \\
b \\
(\mathrm{SE})\end{array}$ & $\begin{array}{c}5 \\
b \\
\text { (SE) }\end{array}$ & $\begin{array}{c}6 \\
b \\
\text { (SE) }\end{array}$ & $\begin{array}{c}7 \\
b \\
\text { (SE) }\end{array}$ \\
\hline $\begin{array}{l}\text { \% Metropolitan popula- } \\
\text { tion }\end{array}$ & $\begin{array}{l}.192 \\
(.184)\end{array}$ & $\begin{array}{l}.185 \\
(.184)\end{array}$ & $\begin{array}{l}.166 \\
(.175)\end{array}$ & $\begin{array}{l}.146 \\
(.186)\end{array}$ & $\begin{array}{l}.192 \\
(.183)\end{array}$ & $\begin{array}{l}.204 \\
(.184)\end{array}$ \\
\hline \% Black population & $\begin{array}{l}-.962^{*} \\
(.376)\end{array}$ & $\begin{array}{l}-.977 * * \\
(.377)\end{array}$ & $\begin{array}{l}-.953 * * \\
(.376)\end{array}$ & $\begin{array}{c}-.918^{*} \\
(.375)\end{array}$ & $\begin{array}{l}-.955^{*} \\
(.377)\end{array}$ & $\begin{aligned}-.972 * \\
(.375)\end{aligned}$ \\
\hline$\% 16-34$ Years of age & $\begin{array}{l}-.155 \\
(.121)\end{array}$ & $\begin{array}{l}-.161 \\
(.122)\end{array}$ & $\begin{array}{l}-.152 \\
(.121)\end{array}$ & $\begin{array}{l}-.161 \\
(.121)\end{array}$ & $\begin{array}{l}-.157 \\
(.121)\end{array}$ & $\begin{array}{l}-.151 \\
(.121)\end{array}$ \\
\hline Divorce rate & $\begin{array}{l}.849^{*} \\
(.417)\end{array}$ & $\begin{array}{l}.871 \\
(.419)\end{array}$ & $\begin{array}{l}.850^{*} \\
(.417)\end{array}$ & $\begin{array}{l}.864^{*} \\
(.415)\end{array}$ & $\begin{array}{l}.858 * \\
(.419)\end{array}$ & $\begin{array}{l}.836 * \\
(.417)\end{array}$ \\
\hline Unemployment rate & $\begin{array}{l}.042 \\
(.042)\end{array}$ & $\begin{array}{l}.041 \\
(.042)\end{array}$ & $\begin{array}{l}.036 \\
(.043)\end{array}$ & $\begin{array}{l}.037 \\
(.042)\end{array}$ & $\begin{array}{l}.043 \\
(.042)\end{array}$ & $\begin{array}{l}.042 \\
(.042)\end{array}$ \\
\hline$\%$ AFDC population & $\begin{array}{l}-.296 \\
(.351)\end{array}$ & $\begin{array}{l}-.307 \\
(.352)\end{array}$ & $\begin{array}{l}-.295 \\
(.351)\end{array}$ & $\begin{array}{l}-.264 \\
(.350)\end{array}$ & $\begin{array}{l}-.290 \\
(.352)\end{array}$ & $\begin{array}{l}-.296 \\
(.350)\end{array}$ \\
\hline $\begin{array}{l}\% \text { in Abolition jurisdic- } \\
\text { tions }\end{array}$ & $\begin{array}{l}.003 \\
(.012)\end{array}$ & $\begin{array}{l}.002 \\
(.012)\end{array}$ & $\begin{array}{l}.001 \\
(.013)\end{array}$ & $\begin{array}{l}.003 \\
(.012)\end{array}$ & $\begin{array}{c}.004 \\
(.012)\end{array}$ & $\begin{array}{l}.004 \\
(.012)\end{array}$ \\
\hline No. of total executions & $\begin{array}{l}-.016 \\
(.030)\end{array}$ & $\begin{array}{l}-.010 \\
(.031)\end{array}$ & $\begin{array}{l}-.007 \\
(.031)\end{array}$ & $\begin{aligned}-.003 \\
(.031)\end{aligned}$ & $\begin{array}{l}-.018 \\
(.031)\end{array}$ & $\begin{array}{c}-.017 \\
(.030)\end{array}$ \\
\hline Artist drawings $(0 / 1)$ & $\begin{array}{l}.015 \\
(.161)\end{array}$ & - & - & - & - & - \\
\hline Witness accounts $(0 / 1)$ & - & $\begin{array}{l}-.091 \\
(.119)\end{array}$ & $\overline{-}$ & - & - & - \\
\hline $\begin{array}{l}\text { Last words presented } \\
\qquad(0 / 1)\end{array}$ & - & - & $\begin{array}{l}-.127 \\
(.135)\end{array}$ & - & - & - \\
\hline $\begin{array}{l}\text { Deserving offenders } \\
(0 / 1)\end{array}$ & - & - & - & $\begin{array}{l}-.200 \\
(.146)\end{array}$ & - & - \\
\hline $\begin{array}{l}\text { Nondeserving offenders } \\
(0 / 1)\end{array}$ & - & - & - & - & $\begin{array}{l}.035 \\
(.149)\end{array}$ & - \\
\hline Execution protests $(0 / 1)$ & - & - & - & - & - & $\begin{array}{l}.075 \\
(.125)\end{array}$ \\
\hline $\begin{array}{l}\text { Intercept } \\
R^{2}\end{array}$ & $\begin{array}{r}-.159 \\
.309\end{array}$ & $\begin{array}{l}.757 \\
.310\end{array}$ & $\begin{array}{r}1.732 \\
.310\end{array}$ & $\begin{array}{r}2.854 \\
.316\end{array}$ & $\begin{array}{r}-.209 \\
.309\end{array}$ & $\begin{array}{r}-1.030 \\
.311\end{array}$ \\
\hline
\end{tabular}


the execution of "nondeserving" persons, and antideath penalty protests are associated with slightly higher rates of police killing, but only at a chance level. Although not shown here, the same patterns hold when the analysis is repeated considering the number of executions for police killings as the certainty measure.

The analyses presented in Tables 1 and 2 were repeated considering rates for each of the four types of police killing: on-duty police killings, off-duty police killings, general jurisdiction police killings, and special police killings. In each case, the pattern of findings was nearly identical to those presented for total police homicides. There was no indication of deterrence for any type of police killing. In the interests of brevity, we do not present these null findings in tabular form.

\section{First-Difference Analyses}

As discussed earlier, our measures of police killing rates are limited because the number of police employees, rather than sworn personnel, is used as the denominator in forming rates. To determine if this limitation is responsible for our nondeterrence findings, first-difference analyses were conducted where we examine the correspondence between month-to-month changes in the death penalty and control variables, and changes in the (1) total number of police killings, and (2) number of different types of police homicide. Table 3 reports the results of the first-difference analysis when the amount of publicity is considered and the total number of police killings is the dependent variable.

Here, we find positive but nonsignificant associations between total police killings and the portion of the U.S. population in abolitionist jurisdictions, the number of total executions (columns 2-4), police-related executions (columns 5-7), the execution publicity dummy variable, and the number of minutes of news coverage of executions. Changes in the number of days of news coverage of executions and the number of police killings are associated negatively as deterrence theory predicts $(b=-.142$ and -.074$)$, but the coefficients are not significant.

As before, we extended the first-difference analysis to consider homicides for different types of police. The findings of these analyses for the killing of onand off-duty police, and regular and special police, parallel very closely those reported in Table 3. Since there is no indication of deterrence, we do not present these results in tabular form.

First-difference analyses were also conducted examining types of media coverage of executions. These results, which are presented in Table 4, show a pattern that is very similar to the results of the rate analysis (Table 2). Total police killings were not found to be related significantly to (1) percent abolition population, (2) total executions or executions resulting from police killings (not shown), or (3) the six types of television coverage.

Although not shown here, the first-difference analysis was further extended to consider the four types of police killing. Here too the null pattern prevailed 
Table 3. First-Difference Autoregressive Analysis of Rates of Total Police Killings, Executions, and the Amount of Execution Publicity, 1976-1989

\begin{tabular}{|c|c|c|c|c|c|c|}
\hline Predictor Variables & $\begin{array}{c}2 \\
b \\
(\mathrm{SE})\end{array}$ & $\begin{array}{c}3 \\
b \\
\text { (SE) }\end{array}$ & $\begin{array}{c}4 \\
b \\
(\mathrm{SE})\end{array}$ & $\begin{array}{c}5 \\
b \\
\text { (SE) }\end{array}$ & $\begin{array}{c}6 \\
b \\
(\mathrm{SE})\end{array}$ & $\begin{array}{c}7 \\
b \\
(\mathrm{SE})\end{array}$ \\
\hline $\begin{array}{l}\text { \% Metropolitan popula- } \\
\text { tion }\end{array}$ & $\begin{array}{c}.890 \\
(2.415)\end{array}$ & $\begin{array}{c}.851 \\
(2.401)\end{array}$ & $\begin{array}{c}.688 \\
(2.399)\end{array}$ & $\begin{array}{c}1.039 \\
(2.397)\end{array}$ & $\begin{array}{r}.984 \\
(2.392)\end{array}$ & $\begin{array}{r}.903 \\
(2.388)\end{array}$ \\
\hline$\%$ Black population & $\begin{array}{l}-.750 \\
(8.663)\end{array}$ & $\begin{array}{l}-.921 \\
(8.709)\end{array}$ & $\begin{array}{c}-1.005 \\
(8.653)\end{array}$ & $\begin{array}{l}-.738 \\
(8.741)\end{array}$ & $\begin{array}{l}-.905 \\
(8.780)\end{array}$ & $\begin{array}{r}-1.072 \\
(8.744)\end{array}$ \\
\hline$\% 16-34$ Years of age & $\begin{array}{c}-2.971 \\
(2.383)\end{array}$ & $\begin{array}{c}-3.006 \\
(2.400)\end{array}$ & $\begin{array}{l}-2.913 \\
(2.374)\end{array}$ & $\begin{array}{c}-3.041 \\
(2.411)\end{array}$ & $\begin{array}{l}-3.085 \\
(2.427)\end{array}$ & $\begin{array}{r}-3.007 \\
(2.412)\end{array}$ \\
\hline Divorce rate & $\begin{array}{c}6.718 \\
(4.602)\end{array}$ & $\begin{array}{c}6.833 \\
(4.622)\end{array}$ & $\begin{array}{c}6.689 \\
(4.599)\end{array}$ & $\begin{array}{c}6.668 \\
(4.619)\end{array}$ & $\begin{array}{c}6.737 \\
(4.634)\end{array}$ & $\begin{array}{c}6.621 \\
(4.625)\end{array}$ \\
\hline Unemployment rate & $\begin{array}{l}.810 \\
(.612)\end{array}$ & $\begin{array}{l}.816 \\
(.617)\end{array}$ & $\begin{array}{l}.792 \\
(.610)\end{array}$ & $\begin{array}{l}.804 \\
(.618)\end{array}$ & $\begin{array}{l}.812 \\
(.623)\end{array}$ & $\begin{array}{l}.784 \\
(.619)\end{array}$ \\
\hline$\%$ AFDC population & $\begin{array}{l}-5.066 \\
(6.239)\end{array}$ & $\begin{array}{c}-5.082 \\
(6.292)\end{array}$ & $\begin{array}{c}-5.013 \\
(6.212)\end{array}$ & $\begin{array}{l}-5.099 \\
(6.339)\end{array}$ & $\begin{array}{c}-5.129 \\
(6.386)\end{array}$ & $\begin{array}{r}-5.068 \\
(6.341)\end{array}$ \\
\hline $\begin{array}{l}\% \text { in Abolition jurisdic- } \\
\text { tions }\end{array}$ & $\begin{array}{l}.141 \\
(.196)\end{array}$ & $\begin{array}{l}.141 \\
(.198)\end{array}$ & $\begin{array}{l}.132 \\
(.196)\end{array}$ & $\begin{array}{l}.148 \\
(.199)\end{array}$ & $\begin{array}{l}.151 \\
(.202)\end{array}$ & $\begin{array}{l}.142 \\
(.200)\end{array}$ \\
\hline No. of total executions & $\begin{array}{l}.169 \\
(.269)\end{array}$ & $\begin{array}{l}.180 \\
(.263)\end{array}$ & $\begin{array}{l}.232 \\
(.273)\end{array}$ & - & - & - \\
\hline $\begin{array}{l}\text { No. of police-related } \\
\text { executions }\end{array}$ & - & - & - & $\begin{array}{l}.444 \\
(.725)\end{array}$ & $\begin{array}{l}.465 \\
(.719)\end{array}$ & $\begin{array}{l}.508 \\
(.729)\end{array}$ \\
\hline $\begin{array}{l}\text { TV publicity dummy } \\
(0 / 1) \text { variable }\end{array}$ & $\begin{array}{l}.147 \\
(.677)\end{array}$ & $\overline{-}$ & - & $\begin{array}{l}.227 \\
(.646)\end{array}$ & - & - \\
\hline $\begin{array}{l}\text { No. of minutes of execu- } \\
\text { tion coverage }\end{array}$ & - & $\begin{array}{l}.007 \\
(.068)\end{array}$ & - & - & $\begin{array}{l}.017 \\
(.066)\end{array}$ & - \\
\hline $\begin{array}{l}\text { No. of days of execution } \\
\text { coverage }\end{array}$ & - & - & $\begin{array}{l}-.142 \\
(.353)\end{array}$ & - & - & $\begin{array}{r}-.074 \\
(.333)\end{array}$ \\
\hline $\begin{array}{l}\text { Intercept } \\
R^{2}\end{array}$ & $\begin{array}{r}-.066 \\
.030\end{array}$ & $\begin{array}{r}-.065 \\
.030\end{array}$ & $\begin{array}{r}-.063 \\
.031\end{array}$ & $\begin{array}{r}-.067 \\
.030\end{array}$ & $\begin{array}{r}-.066 \\
.030\end{array}$ & $\begin{array}{r}-.064 \\
.030\end{array}$ \\
\hline
\end{tabular}

with one exception. The first-difference analysis revealed a significant inverse relationship between the execution of "deserving" offenders and the number of killings involving special police both when the certainty of execution is operationalized as the (1) total number of executions $(b=-.461, S E=.203, p<$ $.05)$, and (2) number of executions of police killers $(b=-.461, S E=.197, p<$ .01 ). Over the 1976-1989 period, the execution of "deserving" offenders (multiple victim killers, rape-murderers, and child killers) was associated, on average, with roughly one-half fewer monthly killings of specialized police such as fish and game protectors, customs agents, border patrol, public transportation and housing police, and park rangers. These findings are consistent with deterrence predictions. They suggest that considering month-to-month changes in the number of police killings is preferable to the earlier rate analyses.

However, the findings also raise an obvious question. Why would deterrence be confined solely to one type of execution publicity and one relatively uncommon type of police killing? (Of the 1204 officers killed during the 19761989 period, only 53 involved special police.) Perhaps the execution of "deserving" persons $(n=9)$ is particularly effective in discouraging police homicides. 
However, more than likely, the pattern observed for the first-difference analysis for "deserving" offenders and "special" police killings is a fluke, an artifact stemming from the timing of such killings-i.e., the unusually high number of special police killed $(\tilde{x}=.889)$ during the nine months immediately preceding ( $t$ - 1) the months with television publicity of "deserving" executions. To assess the impact of this pattern, we reestimated the first-difference equations, substituting the average monthly number of special police killings during the 1976-1989 period $(\bar{x}=.316)$ in place of the actual values for the nine months preceding television coverage of "deserving" executions $(\bar{x}=.889)$. The revised firstdifference analysis reveals negative, but chance only associations between police killings and the media coverage of deserving executions. In short, because the nine $t-1$ months had such an atypically high number of killings of special

Table 4. First-Difference Autoregressive Analysis of Rates of Total Police Killings, Executions, and Type of Execution Publicity, 1976-1989

\begin{tabular}{|c|c|c|c|c|c|c|}
\hline Predictor Variables & $\begin{array}{c}2 \\
b \\
(\mathrm{SE})\end{array}$ & $\begin{array}{c}3 \\
b \\
\text { (SE) }\end{array}$ & $\begin{array}{c}4 \\
b \\
\text { (SE) }\end{array}$ & $\begin{array}{c}5 \\
b \\
(\mathrm{SE})\end{array}$ & $\begin{array}{c}6 \\
b \\
\text { (SE) }\end{array}$ & $\begin{array}{c}7 \\
b \\
\text { (SE) }\end{array}$ \\
\hline $\begin{array}{l}\% \text { Metropolitan popula- } \\
\text { tion }\end{array}$ & $\begin{array}{r}.815 \\
(2.373)\end{array}$ & $\begin{array}{c}.868 \\
(2.382)\end{array}$ & $\begin{array}{r}.734 \\
(2.382)\end{array}$ & $\begin{array}{c}.489 \\
(2.380)\end{array}$ & $\begin{array}{r}.764 \\
(2.430)\end{array}$ & $\begin{array}{r}.804 \\
(2.372)\end{array}$ \\
\hline$\%$ Black population & $\begin{array}{l}-.827 \\
(8.617)\end{array}$ & $\begin{array}{l}-.793 \\
(8.648)\end{array}$ & $\begin{array}{l}-1.080 \\
(8.617)\end{array}$ & $\begin{array}{c}-1.324 \\
(8.606)\end{array}$ & $\begin{array}{r}-1.339 \\
(8.803)\end{array}$ & $\begin{array}{r}-1.418 \\
(8.636)\end{array}$ \\
\hline$\% 16-34$ Years of age & $\begin{array}{c}-2.948 \\
(2.368)\end{array}$ & $\begin{array}{c}-2.934 \\
(2.385)\end{array}$ & $\begin{array}{r}-3.010 \\
(2.384)\end{array}$ & $\begin{array}{c}-2.836 \\
(2.364)\end{array}$ & $\begin{array}{r}-3.092 \\
(2.440)\end{array}$ & $\begin{array}{r}-2.969 \\
(2.370)\end{array}$ \\
\hline Divorce rate & $\begin{array}{c}6.756 \\
(4.591)\end{array}$ & $\begin{array}{c}6.834 \\
(4.603)\end{array}$ & $\begin{array}{r}7.326 \\
(4.607)\end{array}$ & $\begin{array}{c}6.504 \\
(4.574)\end{array}$ & $\begin{array}{c}6.581 \\
(4.717)\end{array}$ & $\begin{array}{r}6.508 \\
(4.591)\end{array}$ \\
\hline Unemployment rate & $\begin{array}{l}.805 \\
(.608)\end{array}$ & $\begin{array}{c}.813 \\
(.612)\end{array}$ & $\begin{array}{c}.803 \\
(.613)\end{array}$ & $\begin{array}{l}.748 \\
(.608)\end{array}$ & $\begin{array}{l}.803 \\
(.628)\end{array}$ & $\begin{array}{l}.765 \\
(.610)\end{array}$ \\
\hline$\%$ AFDC population & $\begin{array}{r}-5.050 \\
(6.193)\end{array}$ & $\begin{array}{c}-5.134 \\
(6.250)\end{array}$ & $\begin{array}{c}-5.151 \\
(6.249)\end{array}$ & $\begin{array}{c}-4.813 \\
(6.187)\end{array}$ & $\begin{array}{c}-5.295 \\
(6.419)\end{array}$ & $\begin{array}{r}-4.907 \\
(6.204)\end{array}$ \\
\hline $\begin{array}{l}\% \text { in Abolition jurisdic- } \\
\text { tions }\end{array}$ & $\begin{array}{l}.139 \\
(.195)\end{array}$ & $\begin{array}{l}.131 \\
(.196)\end{array}$ & $\begin{array}{l}.115 \\
(.197)\end{array}$ & $\begin{array}{l}.139 \\
(.194)\end{array}$ & $\begin{array}{l}.140 \\
(.201)\end{array}$ & $\begin{array}{l}.140 \\
(.195)\end{array}$ \\
\hline No. of total executions & $\begin{array}{l}.193 \\
(.257)\end{array}$ & $\begin{array}{l}.247 \\
(.263)\end{array}$ & $\begin{array}{l}.235 \\
(.259)\end{array}$ & $\begin{array}{l}.261 \\
(.261)\end{array}$ & $\begin{array}{l}.195 \\
(.266)\end{array}$ & $\begin{array}{l}.184 \\
(.254)\end{array}$ \\
\hline Artist drawings $(0 / 1)$ & $\begin{array}{l}-.068 \\
(1.178)\end{array}$ & - & - & - & - & - \\
\hline Witness accounts $(0 / 1)$ & - & $\begin{array}{l}-.765 \\
(.852)\end{array}$ & - & - & - & - \\
\hline $\begin{array}{l}\text { Last words presented } \\
\qquad(0 / 1)\end{array}$ & - & - & $\begin{array}{r}-1.115 \\
(.943)\end{array}$ & - & - & - \\
\hline $\begin{array}{l}\text { Deserving offenders } \\
(0 / 1)\end{array}$ & - & - & - & $\begin{array}{l}-1.110 \\
(1.022)\end{array}$ & - & - \\
\hline $\begin{array}{l}\text { Nondeserving offenders } \\
(0 / 1)\end{array}$ & - & - & - & - & $\begin{array}{r}.094 \\
(1.060)\end{array}$ & - \\
\hline Execution protests $(0 / 1)$ & - & - & - & - & - & $\begin{array}{r}.848 \\
(1.042)\end{array}$ \\
\hline $\begin{array}{l}\text { Intercept } \\
R^{2}\end{array}$ & $\begin{array}{r}-.065 \\
.030\end{array}$ & $\begin{array}{r}-.065 \\
.035\end{array}$ & $\begin{array}{r}-.063 \\
.040\end{array}$ & $\begin{array}{r}-.059 \\
.037\end{array}$ & $\begin{array}{r}-.064 \\
.030\end{array}$ & $\begin{array}{r}-.062 \\
.034\end{array}$ \\
\hline
\end{tabular}


police, the results of our original first-difference analysis appear to be artifactual. We simply see no theoretically meaningful way, via deterrence or brutalization, that execution publicity for a future month could influence the level of these types of police killing for the current month.

\section{Summary and Conclusion}

The central focus of deterrence and death penalty research has been to examine the effect of capital punishment on the general homicide rate. With few exceptions, criminologists have ignored the possibility that capital punishment may be more/less effective in preventing different types of killing. Among the exceptions are several investigations of whether police are afforded an added measure of protection against murder by capital punishment (Bailey, 1982; Bailey \& Peterson, 1987; Sellin, 1955). These studies have found no evidence of deterrence, but they are few in number and they suffer from important limitations.

In this investigation we have extended our understanding of this issue by (1) considering different types of police killing, (2) examining the effect of executions in general and the execution of police killers, (3) exploring the effects of different measures of the amount and type of media coverage of executions, and (4) examining the deterrence question with disaggregated monthly data. Despite these innovations, we find no consistent evidence that capital punishment influenced police killings during the 1976-1989 period. This null pattern holds for four of the five dependent variables: the rate and number of killings involving total, on-duty, off-duty, and regular sworn personnel. The first-difference analysis produced one departure from the null pattern for the killing of special police. However, for the reasons detailed above, this result appears to be artifactual.

In sum, for the period under study here, police do not appear to have been afforded an added measure of protection against homicide by capital punishment. Yet our analysis does not resolve the police killings and capital punishment question. Analyses that disaggregate police killings into additional subtypes are needed. Like general homicides, police killings are not homogeneous with regard to victim and offender characteristics, or the circumstances surrounding police-citizen confrontations. For example, aggregate FBI figures for the 19801989 period show that the circumstances surrounding police killings $(n=801)$ vary widely: (1) responses to disturbance calls $(16.5 \%)$, (2) attempting arrests $(40.9 \%)$, (3) handling and transporting prisoners $(4.2 \%)$, (4) investigating suspicious persons $(14.4 \%)$, (5) ambush situations $(8.7 \%)$, (6) traffic pursuits and stops (13.5\%), and (7) killings by mentally deranged persons (1.6\%). It remains to be determined if capital punishment differentially influences police killings that vary along these lines.

In addition, FBI aggregate data and narrative accounts of police killings 
show variation in both officer (age, gender, years of police service, etc.) and offender characteristics (age, race, ethnicity, concurrent involvement in other crimes, prior record, etc.). Recognizing this variation, future researchers should explore whether (1) different types of officers who are dealing with (2) different types of persons in (3) different types of situations are afforded more/less protection against homicide by capital punishment. Examining these questions provides the next logical step toward a more complete understanding of the relationship between police killings and capital punishment.

In the meantime, we recognize that our research is likely to be disappointing to those seeking an empirical basis for developing capital punishment policies. Future research may identify some specific conditions under which the death penalty influences police killings. However, for those attempting to base policies on the current evidence, it must be concluded that deterrence effects largely do not occur, or where they occur they may be offset by brutalizing effects.

\section{References}

Bailey, W. C. (1974). Murder and the death penalty. Journal of Criminal Law and Criminology, 65 , 416-423.

Bailey, W. C. (1975). Murder and capital punishment: Some further evidence. American Journal of Orthopsychiatry, 45, 669-688.

Bailey, W. C. (1977). Imprisonment vs. the death penalty as a deterrent to murder. Law and Human Behavior, 1, 239-260.

Bailey, W. C. (1978). Deterrence and the death penalty for murder in Utah: A time-series analysis. Journal of Contemporary Law, 5, 1-20.

Bailey, W. C. (1979a). An analysis of the deterrence effect of the death penalty in North Carolina. North Carolina Central Law Journal, 10, 29-51.

Bailey, W. C. (1979b). Deterrence and the death penalty for murder in Oregon. Williamette Law Review, 16, 67-85.

Bailey, W. C. (1979c). The deterrent effect of the death penalty for murder in California. Southern California Law Review, 52, 743-764.

Bailey, W. C. (1979d). The deterrent effect of the death penalty for murder in Ohio. Cleveland State Law Review, 28, 51-81.

Bailey, W. C. (1979-80). The deterrent effect of the death penalty: An extended time-series analysis. Omega: The Journal of Death and Dying, 10, 235-259.

Bailey, W. C. (1980a). Deterrence and the celerity of the death penalty: A neglected question in deterrence research. Social Forces, 58, 1308-1333.

Bailey, W. C. (1980b). A multivariate cross-sectional analysis of the deterrent effect of the death penalty. Sociology and Social Research, 64, 183-207.

Bailey, W. C. (1982). Capital punishment and lethal assaults against police. Criminology, 19, 608625 .

Bailey, W. C. (1983). The deterrent effect of capital punishment during the 1950's. Suicide, 13, 95-107.

Bailey, W. C. (1984a). Disaggregation in deterrence and death penalty research: The case of murder in Chicago. Journal of Criminal law and Criminology, 74, 827-859.

Bailey, W. C. (1984b). Murder and capital punishment in the nation's capitol. Justice Quarterly, 1, $211-233$.

Bailey, W. C. (1990). Murder and capital punishment: An analysis of television execution publicity. American Sociological Review, 55, 628-633.

Bailey, W. C., \& Peterson, R. D. (1987). Police killings and capital punishment: The post-Furman period. Criminology, 25, I-25. 
Bailey, W. C., \& Peterson, R. D. (1989). Murder and capital punishment: A monthly time-series analysis of execution publicity. American Sociological Review, 54, 722-743.

Beccaria, C. (1963). On crimes and punishment (H. Paolucci, Trans.). Indianapolis, IN: BobbsMerrill. (Original work published 1764 .)

Bedau, H. A. (1967). The death penalty in America (rev. ed.). New York: Doubleday.

Bentham, J. (1962). The rationale of punishment. In J. Browning (Ed.), Works of Jeremy Bentham (pp. 388-525). New York: Russell and Russell. (Original work published 1843.)

Berns, W. (1979). For capital punishment. New York: Basic Books.

Black, T., \& Orsagh, T. (1978). New evidence on the efficacy of sanctions as a deterrent to homicide. Social Science Quarterly, 58, 616-631.

Bower, R. T. (1985). The changing television audience in America. New York: Columbia University Press.

Bowers, W. J. (1984). Legal homicide: Death as punishment in America. Boston: Northeastern University Press.

Bowers, W. J. (1988). The effect of executions is brutalization, not deterrence. In K. C. Haas \& J. A. Inciardi (Eds.), Capital punishment: Legal and social science approaches (pp. 49-89). Newbury Park, CA: Sage.

Bowers, W. J., \& Pierce, G. (1975). The illusion of deterrence in Isaac Ehrlich's research on capital punishment. Yale Law Journal, 85, 187-208.

Bowers, W. J., \& Pierce, G. (1980). Deterrence or brutalization: What is the effect of executions? Crime and Delinquency, 26, 453-484.

Chambliss, W. J. (1967, Summer). Types of deviance and the effectiveness of legal sanctions. Wisconsin Law Review, 703-719.

Dann, R. (1935). The deterrent effect of capital punishment. Philadelphia, PA: The Committee of Philanthropic Labor of Philadelphia Yearly Meeting of Friends.

Decker, S. H., \& Kohfeld, C. W. (1990). The deterrent effect of capital punishment in the five most active execution states: A time series analysis. Criminal Justice Review, 15, 173-191.

Ehrlich, I. (1975). The deterrent effect of capital punishment: A question of life or death. The American Economic Review, 65, 397-417.

Ehrlich, I. (1977). Capital punishment and deterrence: Some further thoughts and additional evidence. Journal of Political Economy, 85, 741-788.

Forst, B. (1977). The deterrent effect of capital punishment: A cross-state analysis of the 1960's. Minnesota Law Review, 61, 743-767.

Gibbs, J. P. (1975). Crime, punishment and deterrence. New York: Elsevier.

King, D. R. (1978). The brutalization effect: Execution publicity and the incidence of homicide in South Carolina. Social Forces, 57, 683-687.

Layson, S. K. (1985). Homicide and deterrence: An examination of the United States time-series evidence. Southern Economic Journal, 52, 68-89.

Luckenbill, D. (1977). Criminal homicide as a situated transaction. Social Problems, 25, 176-186.

McFarland, S. G. (1983). Is capital punishment a short-term deterrent to homicide? A study of the effects of four recent American executions. Journal of Criminal Law and Criminology, 74. 1014-1030.

Passell, P. (1975). The deterrent effect of the death penalty: A statistical test. Stanford Law Review, $28,61-80$.

Passell, P., \& Taylor, J. (1975). The deterrent effect of capital punishment: Another view (Discussion Paper 74-7509). New York: Columbia University.

Peterson, R. D., \& Bailey, W. C. (1988). Murder and capital punishment in the evolving context of the post-Furman era. Social Forces, 66, 774-807.

Peterson, R. D., \& Bailey, W. C. (1991). Felony murder and capital punishment: An examination of the deterrence question. Criminology, 29, 367-395.

Phillips, D. D. (1980). The deterrent effect of capital punishment: New evidence on an old controversy. American Journal of Sociology, 86, 139-148.

Pindyck, R. S., \& Rubinfeld, D. L. (1976). Econometric models and economic forecasts. New York: McGraw-Hill.

The Roper Organization. (1983). Trends in attitudes towards television and other media: A twenty year review. New York: Television Information Office. 
Savitz, L. (1958). A study of capital punishment. Journal of Criminal Law, Criminology and Police Science, 49, 338-341.

Schuessler, K. (1952). The deterrent effect of the death penalty. Annals, 284, 54-62.

Sellin, T. (1955). The Royal Commission on Capital Punishment, 1949-1953. Report of the Great Britain Parliament (Papers by Command 8932, pp. 17-24). London: H. M. Stationery Office.

Sellin, T. (1959). The death penalty. Philadelphia, PA: American Law Institute.

Sellin, T. (1967). Capital punishment. New York: Harper \& Row.

Stack, S. (1987). Publicized executions and homicide, 1950-1980. American Sociological Review, $52,532-540$

Stack, S. (1990). Execution publicity and homicide in South Carolina. Sociological Quarterly, 3I, $599-611$.

Sutherland, E. (1925). Murder and the death penalty. Journal of the American Institute of Criminal Law and Criminology, 51, 522-529.

van den Haag, E. (1975). Punishing criminals: Concerning a very old and painful question. New York: Basic Books.

van den Haag, E., \& Conrad, J. (1983). The death penalty: A debate. New York: Plenum.

Yunker, J. (1976). Is the death penalty a deterrent to homicide? Some time series evidence. Journal of Behavioral Economics, 5, 1-32.

Zimring, F. E., \& Hawkins, G. (1986). Capital punishment and the American agenda. New York: Cambridge University Press.

Post-print standardized by MSL Academic Endeavors, the imprint of the Michael Schwartz Library at Cleveland State University, 2014 